\title{
The Spanish Legal System For Protecting The Estates Of Disabled People (Critical Analysis Of Law 41/2003 Of 18 November)
}

\author{
María Ángeles Zurilla Cariñana, University of Castilla La Mancha. Spain.
}

\begin{abstract}
This paper is intended to offer a critical analysis of Law 41/2003 on the Protection of Disabled Persons' Estates. The law introduces institutions not previously regulated in the Spanish legal system: protected estate, support contracts and self-guardianship. This ground-breaking law in Europe also provides major reforms in the rules on inheritance, significantly affecting the statutory legacy system regulated by the Spanish Civil Code. Rising life expectancy, more prevalent degenerative diseases and the need to provide for disabled people's future needs on the death of their parents or guardians are key factors justifying the regulation of these concepts. This study analyzes the new provisions, highlighting their most interesting aspects and the difficulties involved in implementing them.
\end{abstract}

Keywords: protected estate, support contract, self-guardianship, inheritance rules

\section{INTRODUCTION}

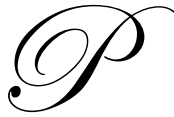

ursuant to article 49 of the Spanish Constitution, many mechanisms seek to provide for the special situation of disabled people. Today it is a reality that many disabled people survive their progenitors due to improved healthcare and other factors, as is the emergence of new forms of disability such as brain and bone-marrow injuries due to road accidents or Alzheimer's disease, which make it advisable for disabled people to receive financial assistance not only by the State or the family but also from their own estate, allowing their future to be safeguarded by providing for other sources to cover their expenses. Law 41/2003 of 18 November on the Protection of Disabled Persons' Estates serves this purpose by regulating new mechanisms for protecting the disabled, focussing on one specific sphere: property.

The law seeks to achieve these aims by means of three concepts: protected estate, support contracts and self-guardianship. It also provides major changes in the Spanish inheritance rules, significantly affecting the system of statutory portions regulated by the Spanish Civil Code, in provisions that have some notable technical deficiecies. follows:

Before studying the new provisions it is worth mentioning some of the main features of Law 41/2003, as

- $\quad$ The introduction for the first time in the sphere of private law of the concept of mental or physical disabiity.

- $\quad$ A distinction between the disabled (people lacking full capacity) and those declared incapable by a court. Disability is conceived as a broader situation than that of incapacity. Disability is a de facto situation requiring no formal constitutive declaration, as it suffices for it to be accredited by a duly issued certificate.

\footnotetext{
${ }^{1}$ This work places in the Project of Investigation financed by The Junta of Castilla-La Mancha (Spain): "Regional Impact of the recent regulation on consumer's law: the regime of arbitration and mediation of consumers, the TR of the LGDCU and the Board of Commercial Improper Practices".
} 
Accordingly the protection offered by the law goes beyond the strict sphere of incapacity, provided for in the events specified in article 200 of the Civil Code.

- $\quad$ New provisions, ground-breaking in Europe, on disabled persons' protected estates.

- $\quad$ The introduction of the concept of self-guardianship.

- $\quad$ An amendment of the system of statutory portions, making changes in the inheritance rules. In the following sections we will analyze the new legal concepts and their most notable features.

\section{DISABLED PERSONS' PROTECTED ESTATES}

Article 1 of Law 41/2003 states that one of its basic aims is to encourage contributions of assets and rights to disabled people's estates, free of charge, and to establish suitable mechanisms to ensure that such property and rights, along with their fruits, products and yields, are assigned to meeting the owner's living needs. Such property and rights will form disabled people's specially protected estates.

The key features of a protected estate are as follows:

- It is a separate estate, in that the property and rights making it up are separated from the rest of the ownerbeneficiary's personal estate. But the lawmakers' intention of establishing a separation between a disabled person's protected estate and the rest of his/her personal property is not realized in the law. Accordingly, according to the principle of unlimited personal liability, enshrined in article 1911 of the Spanish Civil Code, the owner of a protected estate now has two estates with interconnected liability.

- It is an earmarked estate. Its purpose is to meet its owner's living needs.

- It is an estate subject to administrative supervision or specific private control, either by the disabled person him/herself, by the family or by a non-profit institution.

- To encourage the establishment of protected estates the law adopts a number of tax measures involving the grant of tax benefits through changes to personal income tax and corporate tax - a tax not regulated in the same way all over Spain (Chapter III). No provisions are made, however, as to inheritance and gift tax. Nor is anything provided to reduce notarial and registration fees, as would have been desirable.

\section{In personam aspects}

There are two in personam figures: the beneficiary and the settlor. The beneficiary of the protected estate is the disabled person in whose interest it is settled. For the purposes of the law, a disabled person is deemed to be a person affected by a mental impairment of $33 \%$ or more or a physical or sensorial impairment of $65 \%$ or more (article 2). As it may occur that those declared incapable by a court have neither of these degrees of disability, the lawmakers may be criticized for not directly including such incapacitated subjects as beneficiaries of protected estates, without the need to obtain a declaration of disability to the degrees specified by the law. The protected estate must have a single beneficiary; it would have been desirable for the law to provide for the possibility of a single protected estate having two beneficiaries, especially in the case of families with two or more disabled siblings and lacking sufficient resources to fund two protected estates. A protected estate may be settled by the following persons:

- $\quad$ The disabled beneficiary him/herself, provided that he/she has sufficient capacity to act

- $\quad$ His/her parents, guardians or trustees where the disabled person lacks sufficient capacity to act

- $\quad$ The de facto guardian of a mentally disabled person may settle on him/her a protected estate with any property that his/her parents or guardians may have left as an inheritance or that may be receivable through pensions provided by them.

- Any person with a legitimate interest may propose to the disabled person, if he/she has sufficient capacity, or otherwise to his/her parents, guardians or trustees, the settlement of a protected estate, while at the same time offering a suitable contribution of property or rights for the purpose. In the event of an unjustified refusal by the parents or guardians, the proposer may apply to the prosecution service, which will call on the appropriate judge to take steps in the disabled person's interests (article 3). 


\section{In rem aspects}

he in rem aspect of the protected estate is a contribution that may consist either of actual property or of property rights. It will also draw on the fruits, products and yields of such property, as specified in article 1.1 of the law. The property contributed must be of sufficient quantity to meet the disabled person's needs (which may be very hard for the notary to quantify) and must be of a transferable nature. In accordance with the object of a protected estate, i.e. of meeting the owner's living needs, Law 1/2009 of 25 March, reforming Law 41/2003 on the Protection of Disabled Persons' Estates, adds a point to the second paragraph of the latter law's article 5 according to which cash expenses and expendable goods consumed from the protected estate will not be regarded as disposals where the object is to meet the beneficiary's living needs.

The initial contributions may be subsequently added to either by the settlor or settlors or by third parties. Such contributions must always be free of charge (subject to the rules for gifts) and may not be made on deferred terms.

The protected estate may also be added to by deferred legacies or bequests to the estate, with the peculiarity that they shall always be deemed to be made subject to inventory.

\section{Formal aspects}

A protected estate may be settled in two ways: in a public document or by court order (in the event of unjustified refusal by the parents or guardians).

The public document must contain at least an inventory of the property and rights initially forming the protected estate, a statement of the administration and auditing rules, and any other provisions considered appropriate in respect of the estate's administration or preservation. Notaries will immediately notify the public prosecutor in the district of the disabled person's domicile of the settlement and content of a protected estate authorized by them, using an advanced electronic signature. They will likewise serve notice of notarial documents relating to contributions of any kind made subsequent to the settlement (article 3, as formulated in Law 1/2009 of 25 March, reforming Law 41/2003 on the Protection of Disabled Persons' Estates).

The protected estate may, as we said above, receive contributions subsequent to the initial settlement, which will be subject to these same formalities. The requirement for subsequent contributions of property or rights of any kind also to be made in a public document may be criticized, for despite the tax exemptions, the cost of notarial fees (or legal costs and expenses, where applicable) may be an obstacle to the growth of such estates.

Law 41/2003 provides a number of measures for publicity through public registers, for the purpose of giving legal certainty to the disabled person and to the protected estate itself. These are as follows (article 8 , as formulated in Law 1/2009 of 25 March, reforming Law 41/2003 on the Protection of Disabled Persons' Estates):

- $\quad$ Publicity through the Civil Status Register, recording the legal representation granted to the trustee (this registration is provided for only in the event that the trustee of the protected property is not the beneficiary or his/her parent, guardian or trustee).

- $\quad$ Publicity through the Property Register, recording the nature of property or rights in rem registered as part of the protected estate.

- $\quad$ Publicity through other registers. Article 8 paragraph 2 point 2 provides that entries of the same kind will be made in the respective registers as regards any other property liable to be registered. In the case of holdings in investment funds or collective investment institutions, or shares or stakes in trading companies that are part of the protected estate, the notary or the judge will notify the fund manager or company of their new status.

- In all events, public registration must be effected as provided by the regulations, with full respect for the rights to personal and family privacy and legislation on the protection of personal data. 


\section{Administration of the protected estate}

Where the settlor is the protected estate's beneficiary, its administration will be subject to the rules specified in the public settlement document. In other cases, the administrative rules specified in that document must provide the requirement for judicial authorization in the same events in which it is required by the guardian in relation to the protected person's property, in accordance with the provisions of articles 271 and 272 of the Civil Code or, if applicable, according to the applicable provisions of civil, provincial or special law. Such authorization will not be required where the beneficiary has sufficient capacity to act. In no event may persons who cannot be guardians be trustees.

The trustee will be regarded as the beneficiary's legal representative, where he/she is not the beneficiary $\mathrm{him} / \mathrm{herself}$, for all acts by which the property and rights forming the protected estate are administered, and no involvement of the parents or guardian will be required in order for these to be valid and effective (article 5).

Provisions on liability for debts in the administration of protected estates are lacking. It would have been appropriate, as an exception to the principle of unlimited liability specified in article 1911 of the Civil Code, to have provided for a separation of liabilities as a means of strengthening the estate's integrity in respect of potential actions by the beneficiary and the trustee.

The protected estate is subject to supervision by the prosecution service, which may call on the corresponding judge to act on the incapable person's behalf, including for the trustee's replacement, a change in the administration rules, special auditing measures, the adoption of safeguards, the dissolution of the protected estate or any other similar measures (article 7).

The trustee must render accounts to the prosecution service when so required, and in all events once a year. As an external body to support and advise the prosecution service, a Commission for the Protection Disabled Persons' Estates is established, attached to the Ministry of Education, Social Policy and Sport (article 7.3; a paragraph introduced by Law 1/2009 of 25 March, reforming Law 41/2003 on the Protection of Disabled Persons' Estates).

\section{Dissolution}

The protected estate will be dissolved when the beneficiary dies or is declared dead or where he/she ceases to be a disabled person in accordance with article 2.2 of the law.

In the former event the protected estate will be deemed to be part of the person's legacy.

In the latter event the beneficiary will remain the owner of the property and rights forming the estate in accordance with the applicable provisions of the Civil Code (article 6).

\section{SELF-GUARDIANSHIP}

This concept is introduced by Law 41/2003 with the amendment of two articles of the Civil Code: 223 and 234. The former article entitles legally competent persons to take what measures they consider appropriate in anticipation of their own incapacity. Such measures may refer to the appointment of the person that they wish in due course to perform the functions of guardian or trustee; the ruling out of persons that they do not wish to be their legal guardians; instructions as to the healthcare that they wish to receive; a refusal of certain treatments; the settlement of a protected estate, etc. In order to give precedence to the wishes expressed in the document establishing the self-guardianship, article 234 of the Civil Code is amended so as to change the order of preference established therein for persons called upon to become guardians. In the new order, the first person liable to be appointed guardian is the person designated by the person concerned. After him/her the persons called upon are the spouse living with the protected person, the parents, any persons designated by them in their wills, and descendents, relatives in ascending line or siblings appointed by the judge. 
The guardian appointment made by the person concerned must be effected in a notarized will or public document and should be officially notified by the notary responsible for the Civil Status Register. In order for these provisions to be known, the judge is obliged as part of incapacity proceedings to procure the corresponding certificate from the Civil Status Register or the Central Register of Wills. In any event, though the reform is premised on respect for the subject's independent freewill, and provision for self-guardianship is binding for the judge, the judge may, in keeping with the incapacitated person's interests, provide other measures, pursuant to a reasoned court order.

In addition to these provisions on self-guardianship, Law 41/2003 amends article 1732 of the Civil Code to allow in certain cases the continuance of a contract of mandate after the granter has become incapable, namely where the granter him/herself has specified that the contract of mandate should continue in the event of his/her incapacity, and where the mandate is conferred in case of the granter's incapacity, appraised as provided in the Code. In such causes the mandate may be terminated pursuant to a court order issued when the guardianship is established or subsequently at the guardian's request. It would have been desirable for the lawmakers to introduce measures for coordination and harmonization between the provisions on self-guardianship and on precautionary powers of attorney.

Law 41/2003 makes a major amendment to article 757 of the Civil Procedure Law by allowing the presumed incapax to request a declaration of his/her own incapacity, a measure which may be especially useful in the case of degenerative diseases.

\section{SUPPORT CONTRACTS}

Law 41/2003 gives a positive turn to the framework for an aleatory contract well known in legal doctrine: the life annuity contract. Article 12 gives content to articles 1791 to 1797 of the Civil Code by respecifying such contracts, now known as support contracts. These are defined as contracts by which one of the parties undertakes to provide housing, maintenance and assistance to a person throughout his/her life, in exchange for a transfer of capital in any form of property or rights. Their scope is broader than that of the life annuity contract regulated by the Civil Code's articles 1802 et seq.

This is an in personam contract whose term is determined by the life of the receiver of the support. The extent and quality of support will be as specified in the contract, and unless otherwise agreed will not depend on any changing circumstances in the provider's estate and needs or in those of the recipient's estate.

The new provisions' most notable peculiarity is that a default on the support obligation will entitle the recipient to choose between demanding the contract's enforcement or termination, with the application in either case of the bilateral or reciprocal obligations. If the recipient opts to terminate the contract (an option not permitted with a life annuity contract), the person obliged to provide support must immediately restore the property that he/she received under the contract. The judge may determine that such restoration to the recipient should be totally or partially deferred, for the time and with the guarantees specified. The termination should leave the recipient with a remainder that is at least enough to set up a similar pension for the rest of his/her life.

This concept is especially useful where it the parents of the disabled person who transmit capital to the provider in the form of moveable or immovable property, for the benefit of a disabled child.

\section{INHERITANCE RULES}

Law 41/2003 makes major changes to inheritance law, seeking to improve protection for the disabled. These are as follows:

A new grounds of disqualification from succession is specified, namely that of improper conduct, with a section 7 being added to article 756 of the Civil Code. This disqualifies from succession those entitled to inherit from the disabled person who did not provide him/her with due assistance, defined as that regulated by articles 142 et seq. of the Civil Code. The technical construction of this precept is faulty in that it does not specify which persons 
entitled to inherit are being referred to. It is apparent from the explanatory preamble to Law 41/2003 that these persons are the $a b$ intestato heirs. Note that these heirs (children and descendents, parents and relatives in ascending line, spouse, collateral relatives up to the fourth degree and the State) are not the same persons obliged to provide support under article 142 (spouses, relatives in ascending line and descendents; siblings owe only assistance necessary to life, where required for reasons not attributable to the recipient). So the amended article 756 disqualifies persons who are not obliged to provide support under article 142 of the Civil Code from inheritance on grounds of improper conduct. It would have been desirable for the provision to specify which persons are referred to and the content and scope of their obligations in each case, as they are not the same, for example, in the case of the spouse, descendents and relatives in the ascending line as in that of siblings.

The system of statutory portions provided in the Civil Code is significantly modified, as the new formulation of article 782 allows the testator to assign to a substitute trustee the statutory portion of his/her legacy due to a judicially incapacitated child or descendent. It is striking that the testator may impose conditions on the statutory portion of his/her legacy due to his/her children or descendents, and even disinherit them without reason in favour of a disabled descendent, while his/her ability to dispose of the remaining two-thirds of the legacy is not affected, and in relation to this portion the interests of the disabled incapax seem not to count. It would be advisable for the Spanish lawmakers to make a reform of the current inheritance system, allowing greater freedom in willmaking.

Finally a second paragraph is added to article 1041 of the Civil Code, seeking to exclude from legacy calculations any expenses incurred by parents and relatives in ascending line to cover the special needs of their disabled children or descendents.

\section{CONCLUSIONS}

The progressive penetration of women in the labour market (who were traditionally responsible for caring for the elderly and disabled), the changed model of the family, the crisis in the welfare state and insufficient public resources mean that disabled people now require more protection, so it is welcome that the Spanish lawmakers, in amendments to current legal texts and in Law 41/2003, should have provided new mechanisms for protecting disabled people so as anticipate the situation in which they may find themselves when their closest relatives are no longer present or able to look after them.

The concept of a disabled person's protected estate may be useful in protecting disabled people, though it is regulated deficiently. The most notable defects include the fact that such an estate may be settled only on disabled people who have been recognized as suffering the degree of disability specified by the law (33\% or 65\%), so there is no possibility of settling an estate on non-disabled incapable people or those not affected by the legally specified degree of disability.

Also lacking in the law is a regulation of liability for debts in the administration of the estate. In the tax sphere, it would have been desirable for the changes to company tax and personal income tax to have been accompanied by changes in inheritance and gift tax. Given that a protected estate is normally funded by contributions made free of charge, such changes would have encouraged the settlement of protected estates.

With regard to self-guardianship and precautionary powers of attorney, greater coordination and harmonization between the regulations of the two concepts would be desirable.

The changes to the inheritance rules for the benefit of disabled people include notable technical deficiencies which it would be advisable to correct (especially as regards improper conduct and statutory portions).

\section{AUTHOR INFORMATION}

María-Ángeles Zurilla-Cariñana PhD in Law at Castilla La Mancha University, Professor of Civil Law at the Cuenca Social Sciences Faculty (Castilla La Mancha University, Spain). E-mail: MAngeles.Zurilla@uclm.es Research Interest: contract, family and inheritance law and consumer law. 


\section{REFERENCES}

1. Amunátegui Rodriguez. C. (2006): "La constitución de un patrimonio protegido por las personas mayores inicialmente capaces en previsión de su futura pérdida de capacidad", en Libro homenaje al profesor Amorós Guardiola. Vol I, 77-110.

2. Anderson. M. (2006): "El contrato de alimentos: consideraciones en torno a la convivencia de las partes" en Familia, matrimonio y divorcio en los albores del siglo XXI (Lasarte Álvarez- coordinador-), 189-197.

3. Berrocal Lanzarot. A.I. (2005): "El patrimonio protegido del discapacitado en la nueva Ley 41/2003. de 18 de noviembre: una alternativa a la financiación privada. Revista Jurídica de la Comunidad de Madrid, $\mathrm{N}^{\circ}$ 687, 61-118.

4. Cuadrado Iglesias. M. (2004): "Reflexiones acerca del patrimonio protegido de las personas con discapacidad” en Libro Homenaje al Profesor Albaladejo García (González Porras y Pérez González coordinadores-), 1133-1150.

5. Díaz Alabart. S. (2004): "La sustitución fideicomisaria sobre el tercio de legítima estricta a favor del hijo o descendiente" en Revista de Derecho Privado (mayo-junio 2004), 261 y ss.

6. Fernández Gallardo. I. (2007): "La aportación de un bien con reserva de dominio o prohibición de disponer a un patrimonio protegido o a un contrato de alimentos", en Protección jurídica patrimonial de las personas con discapacidad (Pérez de Vargas. J. -coordinador-), 563-582.

7. Gallego Dominguez. I. (2007): “Aproximación al patrimonio protegido del discapacitado”, en Protección jurídica patrimonial de las personas con discapacidad (Pérez de Vargas. J. coordinador-), 113-180.

8. García Pérez. R. (2007): “Titularidad y sujetos constituyentes del patrimonio especialmente protegido del discapacitado" en Protección del patrimonio familiar (Sánchez Calero y García Pérez -coordinadores-), 107-154.

9. Herbosa Martínez. I. (2006): “El patrimonio protegido creado por la Ley 41/2003, de 18 de noviembre, como medida de autoprotección patrimonial de los mayores discapacitados" en Derecho y Mayores (Navarro Mendizábal -coordinador-), 277-294.

10. López-Galiacho Perona. J. (2005): “Aportaciones al estudio del llamado patrimonio protegido del discapacitado", Revista Crítica de Derecho Inmobiliario. № 687, 31-60.

11. Marín Calero. C. (2005): "Comentarios a la Ley de Protección Patrimonial de las personas con discapacidad, en relación con el Patrimonio Protegido de las Personas con Discapacidad", en Jornadas sobre la nueva Ley de Protección Patrimonial de las Personas con Discapacidad (Rueda Pérez. A coordinador-), 39-62.

12. Martín Romero. J.C. (2006): "Del patrimonio y sus clases al patrimonio protegido del discapacitado", Revista Jurídica del Notariado" No 60, 105-160.

13. Martínez Díe. R. (2006): “Algunos puntos críticos en la regulación del patrimonio especialmente protegido del discapacitado" en Los patrimonios protegidos y el trust: III Congreso de derecho civil catalán (Garrido Melero y Nasarre Aznar -coordinadores-), 297-306.

14. Martos Calabrús. M. A. (2004): "El patrimonio protegido de la persona discapacitada (Ley 41/2003, de 18 de noviembre)" en Tendencias actuales en el Derecho de Familia (López San Luis, Pérez Vallejo coordinadoras-), 145-153.

15. Mingorance Gosálvez. C. (2006): "La nueva causa de indignidad para suceder a las personas con discapacidad" en Familia, matrimonio y divorcio en los albores del siglo XXI (Lasarte Álvarez coordinador-), 674-678

16. Moretón Sanz. M. F. (2006): "La figura del administrador del patrimonio especialmente protegido" en Libro Homenaje al profesor Amorós Guardiola. Vol I, 1185-1208.

17. Muñiz Espada. E. (2006): “Trust y patrimonio protegido de las personas con discapcacidad" en "Los patrimonios fiduciarios y el trust: III Congreso de Derecho civil catalán" (Garrido Melero, Nasarre Aznar -) 283-296.

18. Pous Dela Flor. M.P. (2006): "Reflexiones en torno a la Ley 41/2003, de 18 de noviembre, y el sistema de legítima”, en Familia, Matrimonio y Divorcio en los albores del siglo XXI (Lasarte Álvarez -coordinador-), 687-698.

19. Rivera Álvarez. J.M. (2007): "La capacidad de obrar suficiente en el patrimonio protegido de las personas con discapacidad" en Protección jurídica patrimonial de las personas con discapacidad (Pérez de Vargas coordinador-), 721-751. 
20. Ruiz Jiménez. J. (2006): "Delimitación de los conceptos de discapacidad e incapacidad" en Familia, matrimonio y divorcio en los albores del siglo XXI (Lasarte Álvarez -coordinador-), 232-240.

21. Sánchez-Calero Arribas. B. (2006): "La administración y la supervisión del patrimonio protegido creado por la Ley 41/2003, de 18 de noviembre, de protección patrimonial de las personas con discapacidad". Revista Crítica de Derecho Inmobiliario, № 695, 1057-1100.

22. Serrano García. I. (2008): "Protección Patrimonial de las Personas con Discapacidad. Tratamiento sistemático de la Ley 41/2003". Iustel. Madrid.

23. Trigueros Martín. M. J. (2005): "El patrimonio protegido de las personas con discapacidad desde una perspectiva fiscal, tras la Ley 41/2003, de 18 de noviembre" en La familia ante el Derecho Tributario: XIII Congreso Internacional de Derecho de Familia (Lasarte Álvarez -coordinador-), 317-342. 